'Pedagogía en Educación Física, Facultad de Educación, Universidad Autónoma de Chile, Chile.

2Escuela de Kinesiología, Facultad de Salud, Universidad Santo Tomás, Chile.

${ }^{3}$ Escuela de Educación Física, Facultad de Ciencias de la Educación, Universidad Católica del Maule. Talca, Chile. ${ }^{4}$ Departamento de Salud Pública, Facultad de Medicina, CIEDEUCSC, Universidad Católica de la Santísima Concepción. Concepción, Chile.

${ }^{5}$ Laboratorio de Rendimiento Humano. Grupo de Estudio en Educación, Actividad Física y Salud (GEEAFyS). Universidad Católica del Maule. Talca, Chile. ${ }^{6}$ Centro de Investigación en Fisiología del Ejercicio - CIFE, Universidad Mayor. Santiago, Chile. aKinesiólogo.

bProfesor de Educación Física. cNutricionista. ${ }^{\mathrm{MSC}}$. ePhD.

Conflicts of interest: I do not declare.

Correspondence to: Yeny Concha Cisternas yeny.concha@cloud.uautonoma.cl

\section{Association between fitness, anthropometric indices and laboratory parameters in elderly women}

\author{
YENY CONCHA-CISTERNAS ${ }^{1,2, a, d}$, RODRIGO VARGAS-VITORIA ${ }^{3, \mathrm{~b}, \mathrm{e}}$, \\ EDUARDO GUZMÁN MUÑOZ ${ }^{2, \mathrm{a}, \mathrm{e}}$, PABLO VALDÉS-BADILLA ${ }^{1, \mathrm{~b}, \mathrm{e}}$, \\ CLAUDIA TRONCOSO-PANTOJA ${ }^{4, c, d}$, CARLOS CELIS-MORALES $^{5,6, b, \mathrm{e}}$
}

\section{ABSTRACT}

Background: Aging causes an involution of anthropometric and health indices that can affect physical fitness. Aim: To determine the influence of anthropometric and health indices on the physical fitness of elderly women. Material and Methods: Anthropometric parameters, serum lipids, blood glucose and physical fitness evaluated using Senior Fitness Test, were assessed in 140 women aged 70 \pm 5 years. The association between parameters was analyzed using Pearson's correlation coefficient and multiple regression models. Results: In the regression models serum lipids and the suprailiac skinfold were significant predictors of the up and go test $\left(R^{2}=0.48\right)$. HDL cholesterol and the level of physical activity were predictors of the two minutes step test $\left(R^{2}=0.31\right)$. Serum lipids, suprailiac skinfold and age were predictors of the back-scratch test $\left(R^{2}=0.41\right)$. Fasting blood glucose and HDL cholesterol were predictors of the chair sit and reach test $\left(R^{2}=0.24\right)$. Serum lipids and body mass index were predictors of the arm curl test $\left(R^{2}=0.37\right)$. Body mass index and serum lipids were predictors of the chair stand test $\left(R^{2}=0.49\right)$. Conclusions: Anthropometric variables, serum lipid levels and blood glucose were predictors of different physical fitness parameters in these women.

(Rev Med Chile 2020; 148: 1742-1749)

Key words: Pyhsical Fitness; Aged; Public Health; Ageing.

\section{Relación entre la condición física, índices an- tropométricos y parámetros de laboratorio en mujeres adultas mayores}

\footnotetext{
Antecedentes: El envejecimiento causa involución de indices antropométricos $y$ de salud, los cuales pueden afectar la condición física. Objetivo: Determinar la influencia de indices antropométricos y de salud sobre la condición física de mujeres mayores. Material y Métodos: Se evaluaron parámetros antropométricos, lípidos séricos y la condición física mediante el "senior fitness test" en 140 mujeres de $70 \pm 5$ años. La asociación entre variables se evaluó mediante correlaciones simples y modelos de regresión múltiple. Resultados: En los modelos de regresión múltiple, los lípidos séricos y pliegue suprailíaco fueron predictores significativos de la prueba de levantarse, caminar y volver a sentarse $\left(R^{2}=0,48\right)$. El colesterol HDL y el nivel de actividad física fueron predictores de la prueba de dos minutos de marcha $\left(R^{2}=0,310\right)$. Los lípidos séricos, el pliegue suprailíaco
} 
y la edad fueron predictores de la prueba de juntar las manos tras la espalda $\left(R^{2}=0,41\right)$. La glicemia en ayunas y el colesterol HDL fueron predictores de la prueba de flexión del tronco en silla $\left(R^{2}=0,24\right)$. El índice de masa corporal $y$ los lípidos séricos fueron predictores de la prueba de flexo-extensión de codo $\left(R^{2}=0,37\right)$. El indice de masa corporal y los lípidos séricos fueron predictores de la prueba de sentarse y levantarse de una silla $\left(R^{2}=0,49\right)$. Conclusiones: Las variables antropométricas, los lípidos séricos y la glicemia fueron predictores de diversas pruebas de capacidad física en mujeres mayores.

Palabras clave: Condición física, Anciano, Índices antropométricos, Variables de salud, Envejecimiento.

$\mathrm{P}$ rojections by the World Health Organization identify a sustained increase in persons over 60 years of age ${ }^{1}$. It is estimated that between 2015 and 2050, the percentage of the planet's inhabitants over the age of 60 will almost double, from $12 \%$ to $22 \%$, while in Chile, the elderly population will increase from $19.9 \%$ in 2017 to $21.6 \%$ in $2050^{1,2}$.

Ageing is related to the appearance of sarcopenia, loss of muscle strength, deterioration of flexibility, and decreased aerobic endurance, which are morphophysiological changes capable of deteriorating the physical fitness of people and directly affecting their independence and functionality ${ }^{3,4}$. Modifications in body composition have also been reported, which leads to greater accumulation of adipose tissue towards the abdominal region ${ }^{5}$. The increase in visceral fat is associated with a higher risk of metabolic diseases and mortality in older women ${ }^{6}$.

One way to quantify changes in body composition is by using anthropometric indices such as body mass index (BMI), waist circumference (WC), waist-to-height ratio (WHR), and percentage of fat mass ${ }^{7}$. These anthropometric variables, in addition to having broad validity, have additionally been associated with loss of physical fitness and functionality ${ }^{8}$. Several studies point to the BMI, WC, and WHR as strong indices of loss of physical fitness; however, not all authors agree ${ }^{9,10}$.

Otherwise, it has been pointed out that women over 60 years of age maintain an inadequate epidemiological profile, characterized by unfavorable health indices, which become risk factors for the maintenance of functionality ${ }^{11}$. Recent literature shows that older women have a high incidence of dyslipidaemia and type II diabetes mellitus ${ }^{12}$, in addition to poor physical activity and dedicating several hours of the day to seden- tary activities ${ }^{13-15}$. These factors, as a whole, are considered risk factors for the development of chronic non-communicable diseases and the loss of physical fitness ${ }^{12,14,16}$.

Physical fitness corresponds to the physiological ability to perform activities of daily living with normality that depends on the compensation of skills, such as muscle strength, aerobic endurance, flexibility, agility, and dynamic balance ${ }^{17}$. Some health indices, including anthropometric ones, can individually modify the physical fitness of the elderly; however, to date, the works that show how these indices could be related to each other, or conjugated, are limited to the positive or negative influence of physical fitness on the elderly. Therefore, the objective of this study was to determine the influence of anthropometric and health indices on the physical fitness of elderly women.

\section{Materials and Methods}

\section{Study design}

Quantitative research of transversal design was carried out. The sample was obtained through a non-probabilistic sample for convenience, constituted by 140 older women belonging to six community centers in the city of Talca, who met the study selection criteria and were available to participate in the study. Inclusion criteria encompassed: a) seniority greater than or equal to one year in the senior center, b) female sex between the ages of 65 and 75,c) be independent. Women with a score $\geq 43$ points in the Functional Examination of the Older Adults (EFAM-Chile) were considered independent and d) lipid profile and fasting glycemia tests performed in the last three months.

Older women who had a disabling illness, a physical disability that limited their physical-func- 
tional performance or were classified as dependent according to EFAM-Chile ( $\leq 42$ points), a history of surgery in the six months prior to the study, or any chronic uncontrolled disease were excluded.

All women evaluated agreed to participate voluntarily in the study and signed an informed consent form authorizing the use of information for scientific purposes. The research protocol was approved by the Ethics Committee of the Santo Tomás University (No 41/2017), which verified that the procedures followed the ethical considerations of the Helsinki declaration.

\section{Anthropometric indices}

Participants were evaluated barefoot and in light clothes in a room with the necessary conditions to protect their health and privacy. Body weight was determined using Scale-tronix 5002 mechanical portable scale (Welch Allyn ${ }^{\oplus}$, New York, USA) (0.1 kg accuracy).Height was measured in a bipedal position using a stadiometer with a Seca 217 portable scale (Seca, Hamburg, Germany) (0.1 cm accuracy). The BMI was then calculated according to the internationally established criteria, which indicate dividing the body weight by the biped square height $\left(\mathrm{kg} / \mathrm{m}^{2}\right)^{18}$.

Abdominal adiposity was determined through WC measurement using a Sanny brand tape measure (Sanny, Sao Paulo, Brazil) (0.1 cm accuracy), with the individual standing and taking as an anatomical reference the midpoint between the iliac crest and the last rib $^{19}$. WHR was measured by dividing the WC by standing height ${ }^{20}$. Finally, the fat mass was obtained by measuring the bicipital, tricipital, subscapular, and suprailiac skin folds using a Lange Skinfold model C-130 caliper (Creative Health Products, Inc., Ann Arbor, USA) ( $0.5 \mathrm{~mm}$ accuracy), then calculating the percentage of fat mass using the Durnin and Womersley equation ${ }^{21}$. All measurements were taken by trained health professionals.

\section{Laboratory parameters}

Participants were asked for their blood glucose and lipid profile tests. The latter included total cholesterol, triglycerides (TG), high-density lipoprotein cholesterol (c-HDL), low-density lipoprotein cholesterol (c-LDL), and atherogenic index. The atherogenic index was calculated by dividing the values of high-density triglycerides/ lipoproteins (TG/c-HDL) ${ }^{22}$.

\section{International Physical Activity Questionnaire}

The level of physical activity was measured through the short version of the International Physical Activity Questionnaire (IPAQ). Total physical activity was expressed continuously in metabolic-energy equivalents (METs) ${ }^{23,24}$.

\section{Physical fitness}

The physical fitness was determined according to the protocol of evaluations of the Senior Fitness Test ${ }^{25}$. The order of application of the tests included in the battery were: a) Chair Stand Test to assess the strength of the lower body, counting the number of repetitions in $30 \mathrm{~s}$; b) Arm Curl Test to assess the strength on the upper body, using a 3-lb (women) and 5-lb (men) dumbbell, counting the number of repetitions in $30 \mathrm{~s}$; c) a Two-minute Step Test to assess aerobic fitness, registering the number of knee elevations; d) Chair sit and reach Test to assess the flexibility of the lower body, measured in cm; e) Back-scratch Test to assess the flexibility of the upper body, measured in $\mathrm{cm}$; and f) Up-and-go Test to assess agility and dynamic balance, surrounding a cone at 8 feet $(2.44 \mathrm{~m})$ and registering the time in seconds $s^{25}$.

\section{Statistical analysis}

The Statistical Package for Social Science (SPSS) version 23.0 was used for all analyses. The variables were subjected to the KolmogorovSmirnov normality test and a descriptive analysis calculating the mean, standard deviation (SD), and their respective $95 \%$ confidence intervals. A multiple linear regression model was applied using stepwise method to determine the influence of anthropometric and health indices on the physical fitness of the participants. All analyses were adjusted for age and BMI. The level of statistical significance was defined as $\mathrm{p}<0.05$.

\section{Results}

The results of the anthropometric measurements are shown in Table 1. It can be seen that the average age of the participants was $69.50 \pm 4.64$ years. The results of the health and fitness indices are shown in Table 2.

The variables that were significant for the multiple linear regression models are observed in Table 3. For the Up-and-go Test, the variables 
Table 1. Descriptive characteristics of the sample. The mean, standard deviation (SD), and $95 \%$ confidence interval $(95 \% \mathrm{CI})$ for the anthropometric indices analysed are presented

\begin{tabular}{|lcccc|}
\hline & & & \multicolumn{2}{c|}{ Cl 95\% } \\
\hline Personal history & Mean & SD & Minimum & Maximum \\
Age & & & & \\
Anthropometric indicators & 69.50 & 4.64 & 67.97 & 70.93 \\
$\quad$ Body weight $(\mathrm{kg})$ & & & & 74.58 \\
Bipedal stature $(\mathrm{m})$ & 69.94 & 11.47 & 67.24 & 1.59 \\
Body mass index $\left(\mathrm{kg} / \mathrm{m}^{2}\right)$ & 1.580 & 0.03 & 1.560 & 29.91 \\
Waist circumference $(\mathrm{cm})$ & 28.15 & 28.46 & 27.00 & 97.54 \\
Waist-to-height ratio & 95.50 & 9.26 & 91.61 & 0.619 \\
Fat mass $(\%)$ & 0.599 & 0.060 & 0.580 & 39.37 \\
Brachial fold $(\mathrm{mm})$ & 38.60 & 2.83 & 37.55 & 18.81 \\
Tricipital fold $(\mathrm{mm})$ & 16.50 & 5.9 & 14.86 & 25.96 \\
Subscapular fold $(\mathrm{mm})$ & 26.00 & 6.29 & 21.94 & 24.99 \\
Suprailiac fold $(\mathrm{mm})$ & 23.00 & 5.47 & 21.49 & 23.77 \\
\hline
\end{tabular}

Table 2. Descriptive characteristics of the sample. The mean, standard deviation (SD), and $95 \%$ confidence interval $(95 \% \mathrm{Cl})$ are presented for the health and fitness indices analysed

\begin{tabular}{|c|c|c|c|c|}
\hline & \multirow[t]{2}{*}{ Mean } & \multirow[t]{2}{*}{ SD } & \multicolumn{2}{|c|}{$\mathrm{Cl} 95 \%$} \\
\hline & & & Minimum & Maximum \\
\hline \multicolumn{5}{|l|}{ Health indicators } \\
\hline Blood glucose (mg/dl) & 96.50 & 28.49 & 95.09 & 113.3 \\
\hline Total cholesterol (mg/dl) & 226.0 & 41.85 & 211.4 & 238.1 \\
\hline $\mathrm{TG}(\mathrm{mg} / \mathrm{dl})$ & 151.0 & 64.16 & 130.2 & 171.2 \\
\hline $\mathrm{c}-\mathrm{LDL}(\mathrm{mg} / \mathrm{dl})$ & 131.6 & 29.70 & 124.1 & 143.1 \\
\hline $\mathrm{c}-\mathrm{HDL}(\mathrm{mg} / \mathrm{dl})$ & 54.45 & 10.64 & 50.39 & 57.19 \\
\hline Atherogenic index & 4.250 & 1.2 & 3.93 & 4.7 \\
\hline Level of physical activity (METs) & 623.2 & 266.2 & 538.1 & 708.3 \\
\hline \multicolumn{5}{|l|}{ Physical fitness } \\
\hline Up-and-go test (s) & 9.20 & 1.16 & 9 & 9.74 \\
\hline Two-minute step test (repetitions) & 114.5 & 13.44 & 109.1 & 117.7 \\
\hline Chair sit and reach test $(\mathrm{cm})$ & 0 & 4.74 & -0.64 & 2.39 \\
\hline Back scratch test $(\mathrm{cm})$ & -9.5 & 8.39 & -13.59 & -8.22 \\
\hline Arm curl test (repetitions) & 21.0 & 5.64 & 19.47 & 23.08 \\
\hline Chair stand test (repetitions) & 19.0 & 3.69 & 16.92 & 19.28 \\
\hline
\end{tabular}

TG: triglycerides; c-LDL: low-density lipoprotein cholesterol; c-HDL: high-density cholesterol lipoprotein.

that were significant were the total cholesterol c-HDL and suprailiac fold. This model had an explanation level of $47.7 \%$. In the Two-minute Step Test, the model that was significant included the variables c-HDL and level of physical activity, with an explanation level of $31.0 \%$.
In the flexibility tests, the level of explanation of the models was $41.4 \%$ and $24.1 \%$ for the Back-scratch Test and the Chair sit and reach Test, respectively. For the Back-scratch Test, the model indicated that the variables of age, total cholesterol, c-HDL, and suprailiac fold together 
Table 3. Significant multiple linear regression models obtained from physical fitness tests regarding anthropometric and health indicators evaluated

\begin{tabular}{|c|c|c|c|c|c|}
\hline Evaluated test & $\mathbf{R 2}$ & Coefficient B & p value & \multicolumn{2}{|c|}{ IC $95 \%$} \\
\hline & & & & & \\
\hline Total cholesterol (mg/dl) & & 0.009 & 0.014 & 0.002 & 0.016 \\
\hline $\mathrm{c}-\mathrm{HDL}(\mathrm{mg} / \mathrm{dl})$ & & -0.051 & $<0.001$ & -0.078 & -0.024 \\
\hline Suprailiac fold (mm) & & 0.074 & 0.002 & 0.028 & 0.119 \\
\hline Two-minute step test & 0.310 & & & & \\
\hline $\mathrm{c}-\mathrm{HDL}(\mathrm{mg} / \mathrm{dl})$ & & 0.56 & 0.003 & 0.21 & 0.91 \\
\hline Level of physical activity (METs) & & 0.016 & 0.029 & 0.002 & 0.03 \\
\hline Back scratch test & 0.414 & & & & \\
\hline Age (years) & & -0.549 & 0.043 & -1.081 & -0.018 \\
\hline $\mathrm{c}-\mathrm{HDL}(\mathrm{mg} / \mathrm{dl})$ & & 0.337 & 0.002 & 0.127 & 0.547 \\
\hline Total cholesterol (mg/dl) & & -0.059 & 0.033 & -0.112 & -0.005 \\
\hline Suprailiac fold (mm) & & -0.602 & 0.003 & -0.991 & -0.213 \\
\hline Chair sit and reach test & 0.241 & & & & \\
\hline $\mathrm{c}-\mathrm{HDL}(\mathrm{mg} / \mathrm{dl})$ & & 0.208 & 0.004 & 0.007 & 0.106 \\
\hline Blood glucose $(\mathrm{mg} / \mathrm{dl})$ & & 0.057 & 0.027 & 0.073 & 0.344 \\
\hline Arm curl test & 0.371 & & & & \\
\hline $\mathrm{BMI}\left(\mathrm{Kg} / \mathrm{m}^{2}\right)$ & & -0.190 & 0.049 & -0.556 & -0.175 \\
\hline $\mathrm{c}-\mathrm{HDL}(\mathrm{mg} / \mathrm{dl})$ & & 0.191 & 0.013 & 0.044 & 0.338 \\
\hline$c-L D L(m g / d l)$ & & -0.069 & 0.015 & -0.123 & -0.014 \\
\hline Chair stand test & 0.492 & & & & \\
\hline $\mathrm{BMI}\left(\mathrm{Kg} / \mathrm{m}^{2}\right)$ & & -1.053 & 0.011 & -1.848 & -0.258 \\
\hline$c-H D L(m g / d l)$ & & 0.141 & 0.004 & 0.049 & 0.233 \\
\hline c-LDL (mg/dl) & & -0.046 & 0.010 & -0.081 & -0.012 \\
\hline Body weight $(\mathrm{kg})$ & & 0.404 & 0.015 & 0.085 & 0.724 \\
\hline
\end{tabular}

BMI: body mass index; c-LDL: low-density lipoprotein cholesterol; c-HDL: high-density lipoprotein cholesterol.

influence the performance of the test. For its part, no significant model was found for the Chair sit and reach Test.

In the Arm Curl Test, the variables that were significant in the multiple linear regression model were the c-LDL and c-HDL, with an explanation level of $37.1 \%$. Finally, in the Chair Stand Test, the model that was significant included the variables of body weight, BMI, c-LDL, and c-HDL, with an explanation level of $49.2 \%$.

\section{Discussion}

The results of this study reveal that there is an influence of anthropometric and health index on the physical fitness of elderly women belonging to community centers based on models obtained through a multiple linear regression analysis. Specifically, the variables that were associated with a low dynamic balance performance and flexibility were high plasma total cholesterol and greater thickness of the suprailiac fold, adding to these a higher age in the model of the variable of flexibility. On the other hand, in the upper and lower body strength, it was found that the increase in BMI and LDL-c is associated with a lower performance of this aspect of physical fitness. In addition, it was noted that the level of physical activity is an explanatory factor of aerobic endurance. An interesting finding of this study is that c-HDL proved to be a factor that is favorably associated with the performance of all the tests evaluated in the Senior Fitness Test, being significant in all the models obtained from the aforementioned variables.

This research revealed that anthropometric 
indices (higher BMI and greater thickness of the suprailiac fold), and health (high c-LDL and total cholesterol, in addition to low c-HDL) related to the accumulation of adiposity are key factors associated with low performance in physical fitness tests in elderly women. It has been suggested that people who are overweight and obese have limited motor performance due to the morphological changes they suffer from increased body weight, mainly due to abdominal adiposity ${ }^{26,27}$. These changes would cause biomechanical movement restriction that would make it difficult to carry out activities that involve changes in the position of the center of mass, for example, in the dynamic balance Up-and-go Test. A recent study indicates that adiposity would affect the performance of gross motor skills but not fine motor tasks (since it does not involve major changes in the center of mass), which would support the hypothesis of morphological restriction ${ }^{28}$. Likewise, it is believed that the deterioration of physical fitness caused by excess adiposity may result from the inability to keep postural stability ${ }^{26}$. This could be explained by the accumulation of adipose tissue in the vicinity of the joints would increase the inertia of the body segments, affecting joint stiffness and limiting the range of motion. As a result, people with excess weight may have less coordination and, consequently, greater difficulty in performing motor tasks related to physical fitness. In addition, the limitation of the range of motion due to accumulation of adipose tissue in the body areas near the joints could be the cause of the poor performance in the test of joining the hands behind the back observed in our study.

Regarding the low performance of muscle strength in people with greater adiposity, it has been proposed that the accumulation of fat mass could alter the normal mechanisms of force development, due to physiological and neuromuscular changes $^{29}$. Some authors have argued that the myoelectric manifestations related to poor motor behavior are a response of the central nervous system to electrochemical imbalance in muscle fiber, and the reduction in the speed of propagation of intracellular action potential ${ }^{30,31}$. In this sense, myoelectric manifestations related to the generation of force in older adults would be enhanced or exacerbated in the presence of intramuscular and subcutaneous fat. In addition, it can also be noted that people with greater adiposity have less muscle mass; therefore, there is a reduction in muscle strength. A significant relationship between the fat mass and the expression of proinflammatory cytokines in the muscle has also been observed, which could reduce electrochemical balance and neural conductivity ${ }^{32}$. Likewise, it has been seen that overweight individuals have alterations in muscle activation patterns ${ }^{33}$. This would directly affect muscle strength due to lower efficiency in the recruitment of motor units. It is likely that in the elderly women evaluated in our study the anthropometric (higher BMI) and health variables (high c-LDL and low c-HDL) related to the accumulation of adiposity negatively influenced the performance of the strength tests of the Senior Fitness Test.

In general, the literature indicates that people with healthy behaviors, such as regular physical activity, have greater cardiorespiratory capacity and better health, and therefore lower risk of cardiovascular disease ${ }^{34}$. In addition, it has been described that people with high levels of physical activity have higher concentrations of $\mathrm{c}-\mathrm{HDL}^{35}$. On the contrary, a high concentration of total cholesterol and c-LDL has been associated with unhealthy behaviours such as overweight, obesity, and low levels of physical activity ${ }^{35,36}$. Of the plasma lipids, c-HDL and TG are the most sensitive molecules to change their concentration by physical activity. The decrease in the concentration of c-HDL due to sedentary lifestyle is due, among other causes, to the decrease in activity and the amount of the enzyme that limits the catabolism of lipoproteins, specifically lipoprotein lipase, and also to the increase in activity of lipoprotein liver lipase $^{37}$. Both changes favor the decrease in cholesterol and the increase in TG and its recapture by hepatocyte ${ }^{38}$. On the other hand, physical activity promotes the reverse process, since by increasing the activity and mass of lipoprotein lipase, as well as decreasing the activity of hepatic lipoprotein lipase, the increase in c-HDL is favored ${ }^{39}$. Other mechanisms that contribute to the increase in the concentration of c-HDL by exercise are the stimulus in the synthesis of Apo AI apoprotein (structural protein of HDL) and formation of preß1-HDL (nascent HDL), as well as the increase in the enzymatic activity of lecithin: cholesterol acyltransferase (LCAT, cholesterol esterifying protein in HDL) $)^{37,40}$. This is related to the results of our study, where it was possible to observe the 
joint influence of the level of physical activity and c-HDL on the performance in the 2-minute walk test of the older women evaluated. In addition, it would help to understand the influence observed in our c-HDL results on the performance of the physical tests evaluated by the Senior Fitness Test.

Among the limitations of this study is the selection of participants from a non-probabilistic sampling, which may restrict the external representativeness of the study, and although data related to physical activity levels were collected using validated instruments, they could not present the actual conditions of the participants. The cross-sectional nature of the study does not allow establishing causality in associations.

\section{Conclusion}

Anthropometric and health indices are associated together with the physical fitness of older women. This fact suggests encouraging the adequate control and management of the anthropometric and health indices related to the deterioration of physical fitness and, at the same time, encouraging actions that favor the improvement of physical capacities for the benefit of greater autonomy and functional independence in old age.

\section{References}

1. Pan American Health Organization (OPS). Aging and demographic changes. 2017. Available at: https://www. paho.org/salud-en-las-americas-2017/?post_type=post_t_es\&p=314\&lang=es

2. National Statistics Institute. Definitive Results CENSUS, Chile, 2017. Available at: http://resultados.censo2017.cl

3. Brook MS, Wilkinson DJ, Phillips BE, Pérez-Schindler J, Philp A, Smith K, et al. Skeletal muscle homeostasis and plasticity in youth and ageing: impact of nutrition and exercise. Acta Physiol 2016; 216 (1): 15-41.

4. Chang K, Hung C, Li C, Lin Y, Wang T, Tsai K, et al. Reduced flexibility associated with metabolic syndrome in community-dwelling elders. PloS One 2015; 10 (1): e0117167.

5. Fleg J, Morrell C, Bos A, Brant L, Talbot L, Wright J, et al. Accelerated longitudinal decline of aerobic capacity in healthy older adults. Circ J 2005; 112 (5): 674-82.

6. Koster A, Murphy RA, Eiriksdottir G, Aspelund T, Sigurdsson S, Lang TF, et al. Fat distribution and mor- tality: the Ages-Reykjavik Study. Obesity 2015; 23 (4): 893-7.

7. Ortega FB, Sui X, Lavie CJ, Blair SN, editors. Body mass index, the most widely used but also widely criticized index: would a criterion standard measure of total body fat be a better predictor of cardiovascular disease mortality? Mayo Clin Proc 2016: 91 (4): 443-55.

8. Wijnhoven HA, van Bokhorst-de van der Schueren MA, Heymans MW, de Vet HC, Kruizenga HM, Twisk JW, et al. Low mid-upper arm circumference, calf circumference, and body mass index and mortality in older persons. J Gerontol A Biol Sci Med Sci 2010; 65 (10): 1107-14.

9. Valdés Badilla P, Ortega Spuler J, Guzmán Muñoz E, Concha Cisternas Y, Vargas Vitoria R. Anthropometric indexes and physical condition in physically active older men: preliminary study. Nutr. Clin. y Diet. Hosp 2018; 38 (1): 61-5.

10. Valdés-Badilla P, Godoy-Cumillaf A, Ortega-Spuler J, Herrera-Valenzuela T, Durán-Agüero, Zapata-Bastias, et al. [Association between anthropometric indices of health and physical condition in physically active older women]. Salud Publ Mex 2017; 59: 682-90.

11. Tseng LA, Delmonico MJ, Visser M, Boudreau RM, Goodpaster BH, Schwartz AV, et al. Body composition explains sex differential in physical performance among older adults. J Gerontol A Biol Sci Med Sci 2013; 69 (1): 93-100.

12. Leiva A-M, Martínez M-A, Petermann F, Garrido-Méndez A, Poblete-Valderrama F, Díaz-Martínez $\mathrm{X}$, et al. Factors associated with the development of type 2 diabetes mellitus in Chile. Nutr Hosp 2018; 35 (2): 400-7.

13. Rodríguez CR, Magaña RN, Carmona EE, Durañones Góngora S. [Lipid profile and cardiovascular risk factors in geriatric patients. Santiago de Cuba. 2010-2011]. Gac Med Espir 2012; 14 (2): 104-10.

14. Díaz X, Garrido A, Martínez MA, Leiva AM, Álvarez C, Ramírez-Campillo R, et al. [Factors associated with physical inactivity in Chile: results of the National Health Survey 2009-2010] Rev Med Chile 2017; 145 (10): 1259-67.

15. Concha-Cisternas Y, Petermann Fanny, Alex Garrido-Méndez, Ximena Díaz-Martínez, Ana María Leiva, Carlos Salas-Bravo, et al. Characterization of physical activity patterns in different Chilean age groups. Nutr Hosp 2019; 36 (1): 149-58.

16. Silva M, Petrica F, Serrano J, Paulo J, Ramalho R, Lucas $\mathrm{D}$, et al. The sedentary time and physical activity levels on physical fitness in the elderly: A comparative cross sectional study. Int. J. Environ. Res. Public Health 2019; 16 (19): 3697 
17. Rikli RE, Jones CJ. Development and validation of a functional fitness test for community-residing older adults. J Aging Phys Act 1999; 7 (2): 129-61.

18. World Health Organization. Obesity and overweight. Available at:http://www.who.int/hpr/NPH/docs/gs_obesity.pdf

19. Marfell-Jones MJ, Stewart AD, de Ridder JH. International standards for anthropometric assessment. Wellington, New Zealand: International Society for the Advancement of Kinanthropometry 2012.

20. Koch E, Romero T, Manríquez L, Taylor A, Román C, Paredes $\mathrm{M}$, et al. [Waist-height ratio: A better anthropometric predictor of cardiovascular risk and mortality in Chilean adults. Diagnostic nomogram used in the San Francisco Project]. Rev Chil Cardiol 2008; 7 (1): 23-35.

21. Durnin JV, Womersley J. Body fat assessed from total body density and its estimation from skinfold thickness: measurements on 481 men and women aged from 16 to 72 years. Br. J. Nutr 1974; 32 (1): 77-97.

22. Niroumand $S$, Khajedaluee $M$, Khadem-Rezaiyan M, Abrishami M, Juya M, Khodaee G, et al. Atherogenic Index of Plasma (AIP): A marker of cardiovascular disease. Med J Islam Repu. Iran 2015; 29: 240.

23. Ainsworth BE, Haskell WL, Herrmann SD, Meckes N, Bassett DR, Tudor-Locke C, et al. 2011 Compendium of Physical Activities: A Second Update of Codes and MET Values. Med Sci Sports Exerc 2011; 43 (8): 1575-81.

24. Serón P, Muñoz S, Lanas F. [Level of physical activity measured through the international questionnaire on physical activity in the Chilean population]. Rev Med Chile 2010; 138: 1232-9.

25. Rikli RE, Jones CJ. Senior fitness test manual: Human Kinetics Books. Champaign, Il; 2013.

26. Lee JJ, Hong DW, Lee SA, Soh Y, Yang M, Choi KM, et al. Relationship Between Obesity and Balance in the Community-Dwelling Elderly Population: A Cross-Sectional Analysis. Am J Phys Med Rehabil 2020; 99 (1): 65-70.

27. Chivers P, Larkin D, Rose E, Beilin L, Hands B. Low motor performance scores among overweight children: Poor coordination or morphological constraints? Hum Mov Sci 2013; 32 (5): 1127-37.

28. Kakebeeke TH, Lanzi S, Zysset AE, Arhab A, Messerli-Bürgy N, Stuelb K, et al. Association between body composition and motor performance in preschool children. Obesity facts 2017; 10 (5): 420-31.

29. Pajoutan M, Sangachin MG, Cavuoto LA. Central and peripheral fatigue development in the shoulder muscle with obesity during an isometric endurance task. BMC Musculoskelet Disord 2017; 18 (1): 314.

30. Allen D, Westerblad H. Role of phosphate and calcium stores in muscle fatigue. J. Physis 2001; 536 (3): 657-65.

31. Dimitrova N, Dimitrov G. Interpretation of EMG changes with fatigue: facts, pitfalls, and fallacies. J Electromyogr Kinesiol 2003; 13 (1): 13-36.

32. Addison O, Drummond M, LaStayo P, Dibble L, Wende A, McClain D, et al. Intramuscular fat and inflammation differ in older adults: the impact of frailty and inactivity. J Nutr Health Aging 2014; 18 (5): 532-8.

33. Méndez-Rebolledo G, Guzmán-Muñoz E, Ramírez-Campillo R, Valdés-Badilla P, Cruz-Montecinos $\mathrm{C}$, Morales-Verdugo J, et al. Influence of adiposity and fatigue on the scapular muscle recruitment order. Europe PMC 2019; 7: e7175.

34. Myers J, McAuley P, Lavie CJ, Despres J-P, Arena R, Kokkinos P. Physical activity and cardiorespiratory fitness as major markers of cardiovascular risk: their independent and interwoven importance to health status. Progress Cardiovascular Dis 2015; 57 (4): 306-14.

35. Crichton GE, Alkerwi A. Physical activity, sedentary behavior time and lipid levels in the Observation of Cardiovascular Risk Factors in Luxembourg study. Lipids Health Dis 2015;14 (1): 87.

36. Pozo-Cruz D, Magaña $M$, Ballesteros $M$, Porras $M$, Rodríguez Bíes E, Navas P, et al. Influence of functional capacity on lipid profile, muscle damage and biochemical profile among community-dwelling elderly-people. Rev Andal Med Deport 2013; 6 (2): 57-65.

37. Thompson PD, Kantor MA, Cullinane EM, Sady SP, Saritelli A, Herbert PN. Postheparin plasma lipolytic activities in physically active and sedentary men after varying and repeated doses of intravenous heparin. Metabolism 1986; 35 (11): 999-1004.

38. Lewis GF, Rader DJ. New insights into the regulation of HDL metabolism and reverse cholesterol transport. Cir Res 2005; 96 (12): 1221-32.

39. Olchawa B, Kingwell BA, Hoang A, Schneider L, Miyazaki $\mathrm{O}$, Nestel $\mathrm{P}$, et al. Physical fitness and reverse cholesterol transport. Arterioscler. Thromb. Vasc. Biol 2004; 24 (6): 1087-91.

40. Ramos-Jiménez A, Hernández-Torres RP, Torres-Durán $\mathrm{PV}$, Mascher $\mathrm{D}$, Posadas-Romero $\mathrm{C}$, Juárez-Oropeza MA. Ejercicio físico sistemático y sus efectos sobre la concentración de triacilgliceroles, C-HDL y parámetros respiratorios y metabólicos. REB 2006; 25 (4): 108-15. 